University of Nebraska - Lincoln

DigitalCommons@University of Nebraska - Lincoln

Improving Warm-Season Forage Grasses Using Selection, Breeding, and Biotechnology

Kenneth P. Vogel

University of Nebraska-Lincoln, kvogel1@unl.edu

Follow this and additional works at: https://digitalcommons.unl.edu/usdaarsfacpub

Vogel, Kenneth P., "Improving Warm-Season Forage Grasses Using Selection, Breeding, and Biotechnology" (2000). Publications from USDA-ARS / UNL Faculty. 2096.

https://digitalcommons.unl.edu/usdaarsfacpub/2096

This Article is brought to you for free and open access by the U.S. Department of Agriculture: Agricultural Research Service, Lincoln, Nebraska at DigitalCommons@University of Nebraska - Lincoln. It has been accepted for inclusion in Publications from USDA-ARS / UNL Faculty by an authorized administrator of DigitalCommons@University of Nebraska - Lincoln. 


\title{
Improving Warm-Season Forage Grasses Using Selection, Breeding, and Biotechnology
}

\author{
Kenneth P. Vogel \\ USDA-ARS \\ Lincoln, Nebraska
}

Plant breeding is human-directed evolution. Plant breeders manipulate the genetic resources of a species, i.e., its germplasm, to produce plants that are of increased value to humanity. Although humans have successfully manipulated the genetic resources of plants and animals for several thousand years, the science of genetics was not developed until this century. Breeding work on most forage grasses in the USA did not began until the 1930s and initial work was focused on developing strains that had good establishment capability, persistence, high forage and seed yields, and good insect and disease resistance. These are essential attributes of forages (Burton, 1986). This initial breeding work resulted in the development of grasses such as 'Coastal' bermudagrass (Cynodon dactylon L.), 'Lincoln' smooth bromegrass (Bromus inermis Leyss.), and 'Kentucky 31' tall fescue (Festuca arundinacea Schreb.) (Vogel \& Sleper, 1994). Limited animal evaluation was involved in the development of these cultivars. The initial breeding work on warm-season native grasses also began in the mid 1930s as a result of efforts to reseed land damaged by erosion, i.e., the dust bowl, in the Great Plains of the USA.

The native warm-season $\left(\mathrm{C}_{4}\right)$ grasses that have the most potential for use in agriculture are switchgrass [Panicum virgatum L.], big bluestem [Andropogon gerardii Vitman], and indiangrass [Sorghastrum nutans (L.) Nash]. They are tall warm-season $\left(\mathrm{C}_{4}\right)$ grasses that were the dominant grasses of the North American Tallgrass Prairie (Weaver, 1968). Although they are generally associated with the natural vegetation of the Great Plains and the Western Corn Belt, they occur widely throughout North America east of the Rocky Mountains and south of $55^{\circ} \mathrm{N}$. Lat. in grasslands and nonforested areas (Hitchcock, 1971; Stubbendieck et al., 1991). They have been seeded in mixtures in the Great Plains for $>50 \mathrm{yr}$ as pasture and range grasses. In the past $20 \mathrm{yr}$ they have become increasingly important as pasture grasses in the central and eastern USA because of their ability to be productive during the hot months of summer when cool-season grasses are relatively unproductive. Although the grasses belong to different genera, they have similar areas of adaptation, uses, and management requirements. The U.S. Department of Energy recently has identified switchgrass as a potential biomass fuel crop and is

Copyright (C) 2000. Crop Science Society of America and American Society of Agronomy, 677 S. Segoe Rd., Madison, WI 53711, USA. Native Warm-Season Grasses: Research Trends and Issues. CSSA Special Publication no. 30. 
funding breeding and production research on this grass (Vogel, 1996). In a specific adaption zone switchgrass is generally the earliest of these grasses to mature and indiangrass is the latest (Moser \& Vogel, 1995). Other warm-season grasses, both native and introduced, are being used in pasture and rangelands but big bluestem, switchgrass, and indiangrass have the broadest potential area of use.

\section{REPRODUCTIVE AND BOTANICAL CHARACTERISTICS}

Reproductive and botanical characteristics of a species determine the breeding procedures and breeding systems that can be used to develop improved cultivars and strains. The germplasm resources available to a breeder can limit the effectiveness of a breeding program. The two main germplasm resources for plants are native populations (in situ preservation) or seed of collections stored in germplasm depositories.

\section{Big Bluestem}

Big bluestem was the dominant species of the Tallgrass Prairie making up as much as $80 \%$ of the vegetation on some sites (Weaver, 1968). Today it can be found in remnant prairies or in old cemeteries throughout its former range of occurrence. These prairies and older varieties are the best germplasm sources of big bluestem available to plant breeders. Old varieties often represent the best germplasm from earlier collections. Databases of remnant prairies are maintained by state conservation agencies in cooperation with the Nature Conservancy. Seed of cultivars can be obtained from the releasing agency or from the U.S. Department of Agriculture's plant germplasm system. Sand bluestem is an ecotype or subspecies adapted to sandy soils such as the Nebraska Sandhills.

Big bluestem culms can grow to be 1 to $2 \mathrm{~m}$ tall and have numerous basal leaves. The vegetative portions of big bluestem plants are seldom over 50 to $60 \mathrm{~cm}$ high. Often the plants grow in clumps although most plants have short rhizomes (Stubbendieck et al., 1991). Sand bluestem has extensive rhizomes. Both big and sand bluestem can be propagated vegetatively by subdividing plants into clonal segments or ramets. In old plants, the crown can become dense and tough, almost woody, making dividing plants very difficult.

The inflorescence of big bluestem is a purplish-colored panicle with generally three digitate racemes, although it may vary from two to nine racemes. Another common name for big bluestem is Turkey Foot since the inflorescence resembles a turkey's foot. Spikelets are single-flowered and paired; the sessile spikelet is perfect and under most conditions, the pedicellata spikelet is staminate. Fertile pedicellata spikelets are found on some plants (Boe et al., 1983). The seed unit is the entire fertile, sessile spikelet that includes a rachis joint and the pedicel that supported the pedicellata spikelet. The seed has varying degrees of pubescence and has a twisted awn. These characteristics make unprocessed seed very fluffy and difficult to seed with conventional drills. Grassland drills have been developed that can plant the chaffy seed. The seed can be processed to remove the pubescence and appendages (Brown et al., 1983). Unprocessed seed weights typically average 550 seeds $\mathrm{g}^{-1}$ for big bluestem and 230 seeds $\mathrm{g}^{-1}$ for sand bluestem (Wheeler \& Hill, 1957). 
Big bluestem is cross-pollinated by wind and is largely self-incompatible (Law \& Anderson, 1940; Norrmann et al., 1997). Flowering is triggered by long days followed by days with decreasing day length. Anthers begin shedding almost as soon as the inflorescence is out of the boot. Depending on strain and the latitude in which it is grown, pollen shed can occur from July to September. Pollen dispersal per plant may last 7 to $8 \mathrm{~d}$ because of varying maturity of tillers and florets (Jones and Newell, 1946). Less than $5 \%$ of pollen grains are dispersed more than $300 \mathrm{~m}$ (Jones \& Newell, 1946). Pollen size is 35 to $50 \mu \mathrm{m}$ in diameter (Jones \& Newell, 1948). In the Sandhills region of Nebraska natural hybrids of big bluestem and sand bluestem are found on the bench areas above subirrigated meadows where big bluestem is found and the dune hills where sand bluestem is a dominant grass (Barnes, 1986). In controlled crosses, Peters and Newell (1961), demonstrated that sand and big bluestem were completely fertile with each other. Hybrids also were fertile.

The base chromosome number of big and sand bluestem is 10 (Gould, 1968). All released cultivars are $2 n=60$ (Riley \& Vogel, 1982; Vogel, 1997 unpublished data); however, $2 n$ chromosome numbers of 60 (hexaploids) and 90 (enneaploid) have been found in the same prairie location at several sites (Keeler 1990, 1992; Norrmann et al., 1997). The somatic nuclear DNA content is $5.93 \mathrm{pg}$ and $8.92 \mathrm{pg}$, respectively, for the hexaploids and enneaploids (Norrmann et al., 1997). Meiosis in the hexaploids is largely normal with diploid pairing while meiosis in the enneaploid is irregular (Norrmann et al., 1997). The pairing behavior in the hexaploids at meiosis suggests an alloploid origin of the species (Norrmann et al., 1997). The enneaploids are believed to be produced from hexaploids by fertilization of an unreduced gamete by a normal gamete. In megasporogensis, an archesporial cell enlarges and undergoes meiosis to give a linear tetrad of megaspores (Norrmann et al., 1997). In hexaploids, the three megaspores close to the micropyle degenerate and the chalazal one, through successive mitotic division, develops into an embryo sac typical of sexually producing grasses (Norrmann et al., 1997). Microsporogenesis is usually normal in big bluestem (Dewald \& Jahal, 1977). Consequently, quantitative genetic theory and breeding methods applicable to diploid plants can be applied to big bluestem.

Flowering occurs early in the morning with the peak time of pollen dispersal from 4 to 9 a.m. (central standard time; Jones \& Newell, 1946; Norrmann et al., 1997). In controlled pollination studies, pollen germinates shortly after contacting the stigmata (Norrmann et al., 1997). In controlled self pollinations with hexaploids, growth of most pollen tubes is arrested at the stigma-style interface, $<10 \%$ of the pollen tubes reach the ovaries and discharge their contents, and selfed seed set is usually <5\% (Norrmann et al., 1997). In controlled pollinations between different hexaploid plants, pollen tubes grow readily through the stigma, style, and ovary, penetrate the micropyle within $2 \mathrm{~h}$ after pollination, and seed set is usually $>50 \%$ (Norrmann et al., 1997).

\section{Switchgrass}

Switchgrass is an erect warm-season perennial grass (Hitchcock, 1971; Stubbendieck et al., 1991). It grows from 0.5 to $2 \mathrm{~m}$ tall and most tillers produce a seedhead when moisture is adequate. Although the plant can appear as a loose 
bunchgrass, it has short rhizomes and a stand has potential to thicken and form a sod. Plants can be easily subdivided into ramets. The inflorescence is a diffuse panicle 15 to $55 \mathrm{~cm}$ long with spikelets at the end of long branches. Spikelets are twoflowered with the second one being fertile and the first one sterile or staminate. The seed unit is a fertile floret. It is smooth and slick with an indurate lemma and palea that adheres tightly to the caryopsis (Wheeler \& Hill, 1957). The seed threshes clean and is easy to process and plant. There are an average of 860000 seeds $\mathrm{kg}^{-1}$ but there are large seed weight differences among cultivars (Wheeler \& Hill, 1957). Johnson and Boe (1982) found 100-seed weights from 103 to $201 \mathrm{mg}$. Switchgrass is a cross-pollinated plant that is largely self-incompatible (Talbert et al., 1983). Switchgrass has a basic chromosome number of 9 and several levels of ploidy exist (Nielsen, 1944). Most switchgrass cultivars are either tetraploids or octaploids (Hopkins et al., 1996; Lu et al., 1998). Switchgrasses have been divided into lowland and upland types. Lowland types are taller, more coarse, generally more rust (Puccinia graminis) resistant, have a more bunch type growth and may be more rapid growing than upland types (Barnett \& Carver, 1967; Brunken \& Estes, 1975; Cornelius \& Johnston, 1941; Porter, 1966). As indicated by the type description, lowland types are found on flood plains and other similar areas while upland types are found in upland areas that are not subject to flooding. Natural hybrids between the two types have not been identified to date. Because of the high degree of self-incompatibility in switchgrass, breeding methods that require use of inbred lines are not useful. Population improvement breeding methods applicable to diploid plants can be successfully used to improve switchgrass as long as separate tetraploid and octaploid populations are maintained.

\section{Indiangrass}

Indiangrass is a tall warm-season grass with short rhizomes. It has a loose bunch type growth habit since the rhizomes are generally shorter than $30 \mathrm{~mm}$ (McKendrick et al., 1975). Indiangrass height generally ranges from 0.5 to $2 \mathrm{~m}$ and has a yellowish brown to black panicle that ranges from 10 to $30 \mathrm{~cm}$ in length (Hitchcock, 1971; Stubbendieck et al., 1991). It belongs to the Andropogoneae tribe, as does big bluestem, and the spikelet and floret structure is similar to big bluestem. The spikelets are in pairs on the rachis with the sessile one fertile and the pedicellata one rudimentary or absent (Stubbendieck et al., 1991). As with big bluestem, the spikelets disarticulate below the glumes, the glumes and florets are covered with pubescence, and the fertile floret has a twisted awn. The seed unit is the spikelet with appendages and it is extremely fluffy and difficult to plant with conventional grass drills unless it is processed to remove pubescence and seed appendages. For unprocessed seed, there are about 385 seeds $\mathrm{g}^{-1}$ while seed weight of caryopses ranges from 120 to $150 \mathrm{mg} 100 \mathrm{seed}^{-1}$ (Wheeler \& Hill, 1957; Barnett \& Vanderlip, 1969). Some indiangrass seedlots have a considerable amount of dormancy (Emal \& Conard, 1973), depending on cultivar and the season of seed production.

A major portion of indiangrass tillers have been described as biennial (McKendrick et al., 1975). The first year they grow vegetatively and then after overwintering, a tiller will become reproductive. This characteristic can be easily seen by observation of the earliest growth in the spring. The tillers, however, do not ap- 
pear to be obligate biennials since indiangrass will flower the seeding year. Indiangrass normally may flower about 4 to 6 wk later than switchgrass collected in the same area (McKendrick et al., 1975). As the genus name Sorghastrum implies, indiangrass morphologically and chemotaxonomically appears to be closely related to the sorghums (Sorghum sp.). Indiangrass is the only forage grass outside of the sorghum genus known to contain cyanogenic glucosides (Gorz et al., 1979). Several groups have attempted to make sorghum-indiangrass hybrids but with no success (Pedersen et al., 1993). Recent comparisons between indiangrass and sorghum using chloroplast restriction fragment length polymorphisms (RFLPs) indicates that the two species are not closely related (Pedersen et al., 1993).

All of the published cytogenetic reports on North American indiangrasses indicate that they have $2 n=40$ chromosomes and that meiosis is normal (Bragg, 1964; Church, 1929; Riley \& Vogel, 1982). Gould (1975) reported indiangrass to have a complement of $2 n=20,40$, and 80 , although he later indicated that all counts in his records were $2 n=40$ except for one count of $2 n=20$ from Brazil (Gould, 1979, personal communication). The cultivars Nebraska 54, Oto, Holt, and Osage have chromosome numbers of $2 n=40$ (Riley \& Vogel 1982). Indiangrass is cross-pollinated by wind. Some plants will set considerable amounts of selfed seed when several panicles are bagged together in parchment bags but other plants produce almost no seed when selfed (Newell, 1936, unpublished data). In the same reports, Newell noted that selfed lines were similar to open-pollinated lines in germination and establishment. Most of the pollen is shed during an 8-d period with peak times from 6 to 10 a.m. (Jones \& Newell 1946). Because of its reproductive behavior, breeding methods that can be used on big bluestem and switchgrass also can be used on indiangrass.

\section{GENETIC VARIATION}

Plants of switchgrass, big bluestem, and indiangrass are photoperiod sensitive that is under genetic control. Photoperiod requirements for flowering and fall senescence differ depending on latitude of origin and are the primary factors determining cultivar adaptation (Moser \& Vogel, 1995). Southern strains moved north will be exposed to longer than normal photoperiods for a given date because of latitude and as a result they will stay vegetative longer and produce more forage (Cornelius \& Johnston, 1941; McMillian, 1959, 1965; Newell, 1968). Northern strains moved south will be exposed to a shorter than normal photoperiod and will flower early. In a controlled study, Benedict (1941) determined that switchgrass requires short days to induce flowering. In nature, flowering is induced by decreasing day length during early summer. The photoperiod response also appears to influence winter survival. Southern types moved too far north will not survive winters because they stay vegetative too late in the fall. As a general rule, these grasses should not be moved more than $500 \mathrm{~km}$ north of their area of origin because of the possibility of stand losses due to winter injury. The response to photoperiod can be modified by growing degree days to some extent since the flowering date of cultivars will vary from year to year. In addition to photoperiod, the other factor that determines specific adaptation is response to precipitation and the associated hu- 
midity (Moser \& Vogel, 1995). Cultivars from the more arid Great Plains states may develop foliar disease problems when grown in the more humid eastern states. Cultivars based on eastern germplasm may not be as well adapted to drought stress as cultivars based on western germplasm.

Although much of the prairie and grasslands that were once occupied by these grasses were plowed and converted into cropland, remnant prairie sites still exist in most areas and are an invaluable germplasm resource. Genetic variation exists among germplasm collected from specific regions (ecotype variation), among accessions of an ecotype (population variation), and among plants of a population collected from a specific site (Eberhardt \& Newell, 1959; Hopkins et al., 1995b; Vogel \& Pedersen, 1993; Vogel et al., 1994; Vybiral et al., 1993). The natural genetic variation that can be used by plant breeders to improve these grasses is the ecotype and among and within population genetic variation that exists within these species. Genetic studies that have been completed on these grasses are listed below.

Switchgrass: Anderson et al., 1988; Boe \& Johnson, 1987; Eberhardt \& Newell, 1959; Gabrielsen et al., 1990; Godshalk et al., 1986, 1988a,b; Godshalk \& Timothy, 1988a,b; Gunter et al., 1996; Hopkins et al., 1993, 1995a,b, 1996; Hultquist et al., 1996, 1997; Johnson \& Boe, 1982; Newell \& Eberhardt, 1961; Talbert et al., 1983; Vogel et al.,1981c, 1984, 1993.

Big and sand bluestem: Barnes, 1986; Boe \& Ross, 1983; Boe et al.,1983, 1989;

Glewen \& Vogel, 1984; Kneebone, 1956; Newell, 1968; Newell \& Peters, 1961; Peters \& Newell, 1961; Ross et al., 1975; Riley, 1981.

Indiangrass: Barnett et al., 1971; Barnett \& Vanderlip, 1969; Kube et al., 1989; Vogel et al., 1980, 1981a,b, 1994; Weimer et al., 1988.

The conclusions from these studies can be summarized as follows: (i) there is substantial genetic variability both between and within strains of these grasses for most agronomic traits including those that affect or determine forage yield, seed yield, and forage quality and; (ii) heritability values for most important traits range from 20 to $40 \%$ that should make it possible to improve these grasses by breeding; and (iii) correlations among most desirable traits are usually positive, but when negative they are usually not large indicating it should be possible to simultaneously improve several traits without adversely affecting other traits. Molecular genetic research with RFLP and RAPD markers (Hultquist et al., 1996, 1997; Gunter et al., 1996) demonstrates that molecular genetics techniques can be valuable in breeding programs for classifying germplasms. Flow cytometry analyses for determining ploidy level of individual plants for assignment to specific breeding populations is developing into a very effective research tool for grass breeding programs (Hultquist et al., 1996, 1997; Hopkins et al., 1996).

\section{BREEDING SYSTEMS}

The improvement that can be made in a plant breeding program is dependent upon the genetic variability within the species for the traits being selected, the heritability of the traits, the breeder's ability to identify genetically superior plants, the intensity of selection, and the effectiveness of the breeding procedure (Allard, 
1964; Hallauer \& Miranda, 1981). Existence of genetic variability is essential because without it, no progress can be made by breeding. Heritability is the proportion of the variability for a particular trait in a population that is due to genetic differences among plants. Traits such as forage yields in grasses are determined by many genes and are greatly influenced by environment and hence have low heritability values.

Ecotypes or endemic strains found in specific regions and sites have evolved by the genetic mechanisms of mutation, migration, selection, and random drift or chance resulting in between ecotype or endemic strain genetic variability (Falconer, 1981). Eberhardt and Newell (1959) and Hopkins et al.(1995b) documented this between strain variability in switchgrass. Most of the initial breeding work with cross-pollinated grasses used between strain genetic variability (Vogel \& Gabrielsen, 1986; Vogel \& Pedersen, 1993; Alderson \& Sharp, 1994). A large array of native accessions (ecotypes or strains) were collected from the general geographical area (native grasses) or from a climatic analogue (introduced grasses) in which a cultivar of the grass was needed (Fig. 6-1). These collections then were evaluated in uniform nurseries for various agronomic traits. The better accessions were increased for testing in additional environments and based on these tests released directly to the public without any additional breeding work. This procedure was used by many of the state experiment stations and the Plant Materials Centers of the USDA-SCS in developing the initial cross-pollinated grass varieties for different geographical regions of the USA (Alderson \& Sharp, 1994). Examples of grass cultivars developed by this procedure include Blackwell and Nebraska 28 switchgrass. Collection and evaluation of plant introductions and native accessions is an ongoing process with a high national priority since the superior strains identified by this process form the germplasm base for the further improvement of grasses by breeding.

Within strain genetic variability consists of the proportion of the plant-to-plant (phenotypic) variability that exists between plants of a strain that is due to genetic (genotypic) differences among plants (Falconer, 1981; Hallauer \& Miranda, 1981). This variability is very difficult to observe or measure in a typical pasture or rangeland situation. If, however, seed is harvested from the individual plants in a common native prairie site and planted in a space-planted nursery under uniform conditions, phenotypic variation among plants can be readily distinguished. By using population or quantitative genetics procedures, geneticists can determine the proportion of the total plant-to-plant phenotypic variability that is due to genetic differences among plants, i.e., they determine the total genetic variability in a population for specific traits and the heritability of those traits.

Switchgrass, big bluestem, and indiangrass have small florets that are difficult to emasculate, and effective mechanisms for producing hybrids such as cytoplasmic male sterility have not been developed for these grasses. Thus, breeders are limited largely to procedures that use additive genetic variability and that do not require emasculation (Vogel \& Pedersen, 1993). Fortunately, there is substantial additive genetic variability for most traits in these grasses, and efficient breeding methods that do not require emasculation are available for perennial plants that can be vegetatively propagated. Breeding schemes or methods that can be used on perennial grasses such as big bluestem, indiangrass, and switchgrass and the ex- 
pected gain from selection that can be made by using the various schemes are described by Vogel and Pedersen (1993). The two breeding methods that have the most potential of exploiting additive genetic variation are Restricted Recurrent Phenotypic Selection or RRPS (Burton, 1974, 1982) and a modified form of between and within half-sib family selection (B\&WFS) (Asstveit \& Asstveit, 1990; Vogel \& Pedersen, 1993). Both methods are population improvement breeding procedures that use recurrent selection and take advantage of the perennial nature of these grasses and their ability to be vegetatively propagated.

The objective of a recurrent selection breeding program is to change the frequency of desirable genes in a the population and by doing so change the popula-

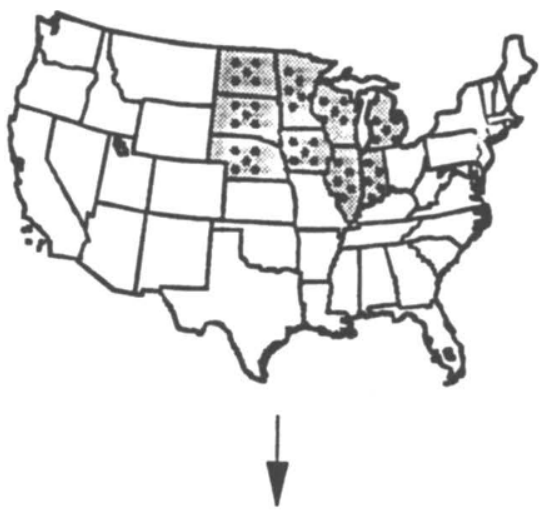

Collection Phase

Plants or seeds collected from

site in specific geographic

region. " = collection sites.

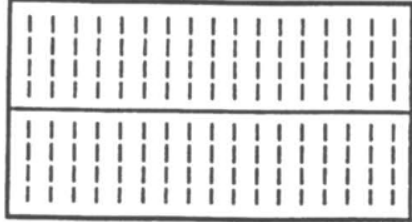

\section{Evaluation Phase}

Collected material evaluated in common evaluation nursery(s).

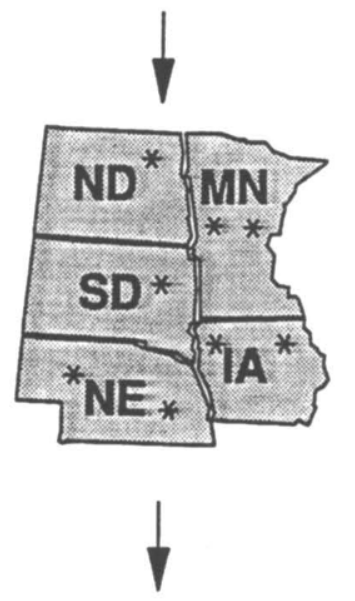

Seed Fields
Advanced Testing

"Best" accessions or strains Increased without additional breeding work and evaluated in replicated trials in specific region.

\section{Release}

"Best" accession or strain released as a cultivar.

Fig. 6-1. Ecotype or naturalized strain selection. Sites of seed collection are indicted by asterisks. 
tion mean. In a theoretical example (Fig. 6-2), the relative yield of a population was improved $16 \%$ in three breeding cycles.

In both RRPS and B\&WFS breeding systems (Fig. 6-3 and 6-4), greenhouse grown seedlings are transplanted into field evaluation nurseries. Limited data are collected the establishment year. The following years are used to collect yield, forage quality data, and other agronomic information. This data then is used to select superior plants that are moved into polycross nurseries. Seed harvested from the

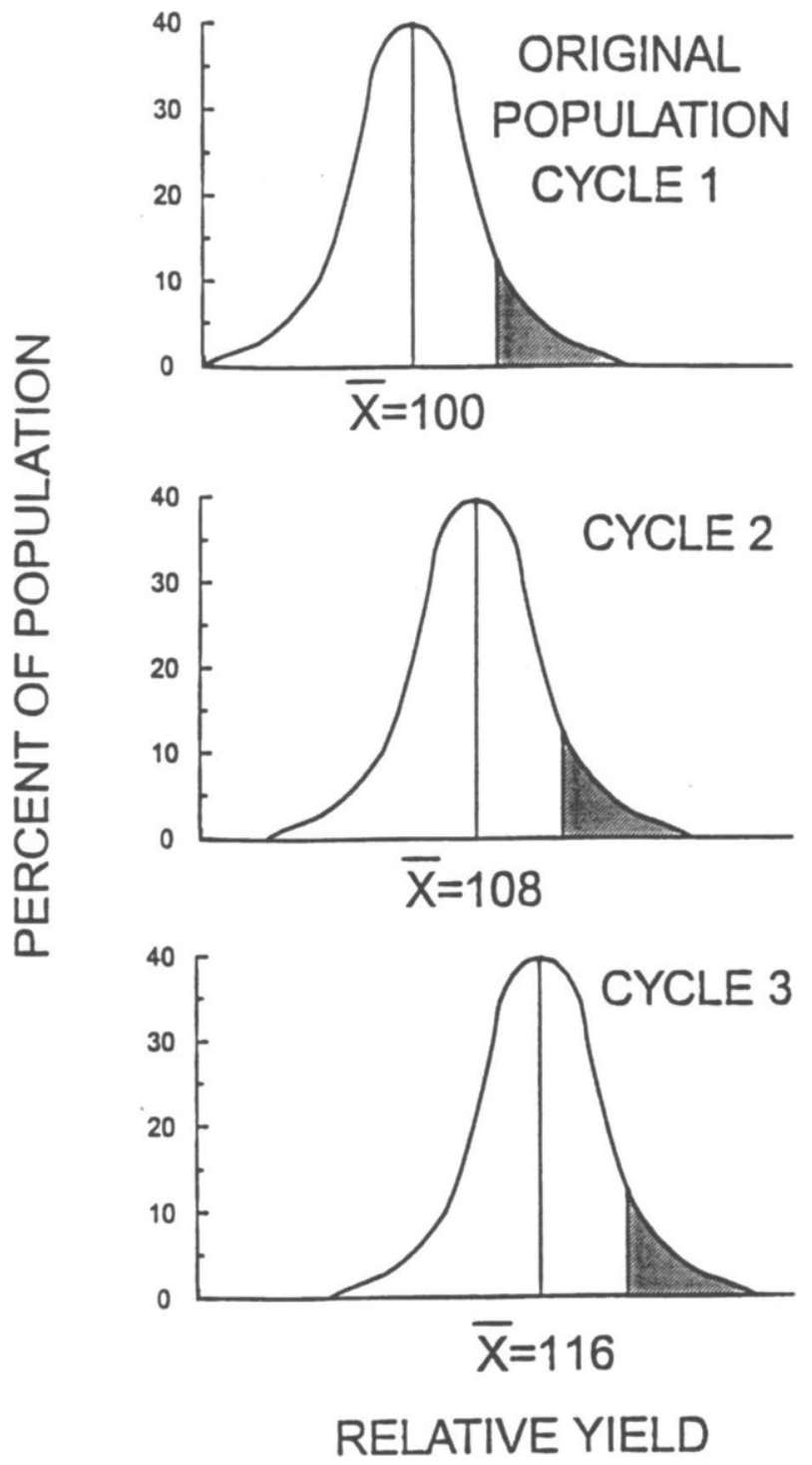

Fig. 6-2. Representation of the theoretical effect of three cycles of restricted, recurrent phenotypic selection on yield. The area under the curve represents all the plants in the population. The shaded area represents the selected plants. In this example 5\% of the highest yielding plants are selected from each cycle, heritability is $40 \%$ and the phenotypic standard deviation is 10 . The population mean $(x)$ of the base population $(\mathrm{C} 0)$ is 100 in Cycle 1. 
polycross nurseries is used to start the next cycle of selection and for yield trials. Each breeding cycle will require 4 or $5 \mathrm{yr}$. A four year cycle is: Year $1-$ establishment; Year 2 and 3-collect data and make selections; Year 4-polycross. A 4 -yr cycle is being used because studies currently being completed indicate that in switchgrass, selection for high in vitro dry matter digestibility (IVDMD) can affect winter survival in some populations and several seasons are necessary to eliminate nonwinter hardy plants. A 5-yr cycle could be used in B\&WFS if 2 yr are used to evaluate families and then $1 \mathrm{yr}$ is used to identify superior individuals in the best families. RRPS was very effective in improving in vitro dry matter digestibility in switchgrass, but yield improvements have been small (Hopkins et al., 1993). The between and within family breeding procedure (Fig. 6-4) provides a method of measuring genetic differences among families and also allows the breeder to maintain adequate population size to avoid inbreeding depression. The expected gains from selection for these two breeding methods are similar if the breeder uses the same number of years per cycle (Vogel \& Pedersen, 1993). The time period required to develop and test a new cultivar can exceed $15 \mathrm{yr}$ particularly if grazing trials are part of the evaluation process (Table 6-1).

Direct selection for a single trait usually will result in the maximum gain from selection for that trait. Multiple trait selection adds to the challenge because the desired traits may have low or negative genetic correlations with one another. In general, grass breeders have made very limited use of formal selection indexes based

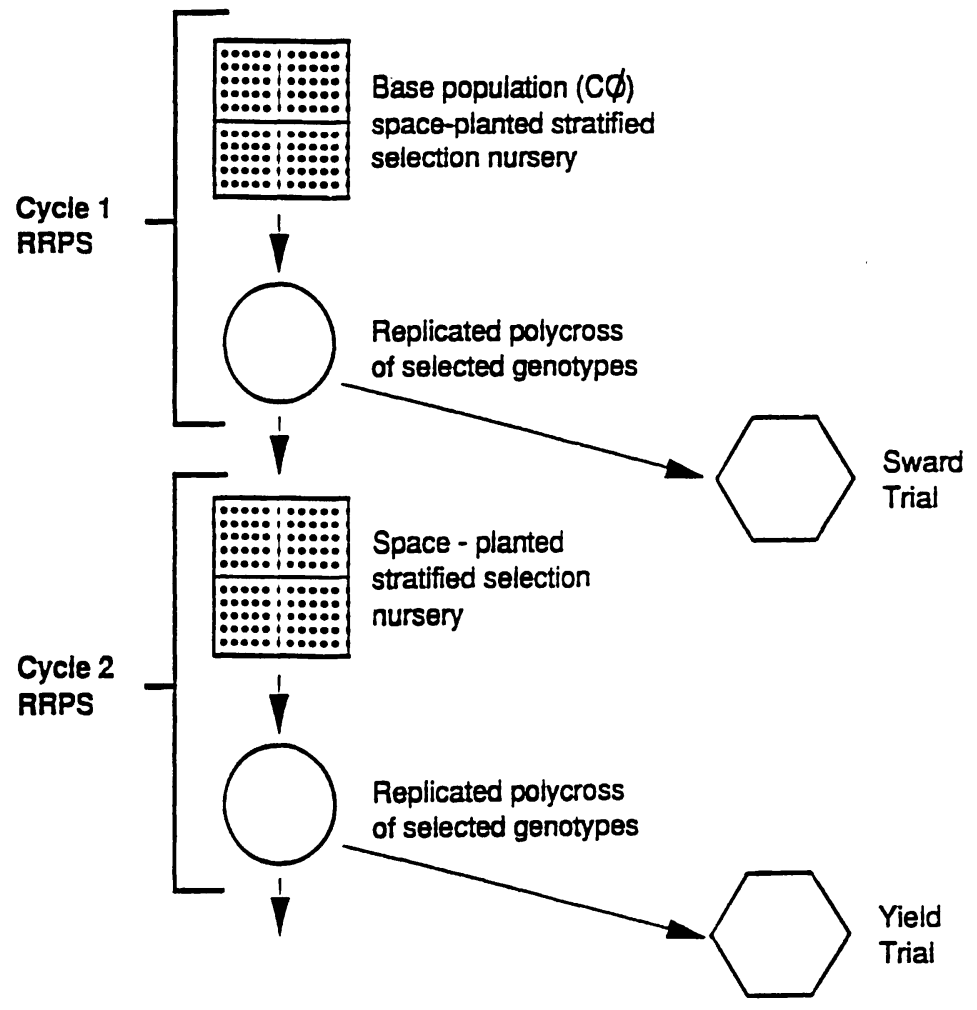

Fig. 6-3. Recurrent, stratified phenotypic selection. 
on quantitative genetic theory but have instead relied on informal subjective indexes. Research by Godshalk and Timothy $(1988 \mathrm{a}, \mathrm{b})$ indicate that selection indexes may be effective in breeding for multiple traits in perennial grasses. The use of selection indexes based on quantitative theory in which traits are weighted by realistic economic values should result in improved breeding efficiency.

Grass breeders in general have not capitalized on the nonadditive genetic variability that exists in forage grasses even though substantial heterosis for traits such as yield exists in many grasses. The inability to effectively emasculate large numbers of plants in seed production fields has limited grass breeders' ability to develop hybrids for commercial use. Techniques that may have application for big bluestem, switchgrass, and indiangrass are: production of first generation chance hybrids, hybrids produced by using self-incompatibility, and the use of male gametocides (Burton, 1986; Vogel et al., 1989). First generation chance hybrids are produced by mixing seed of four lines or families, planting the bulk, and then harvesting the seed. The seed harvested from the seed field should contain $75 \%$ hybrid seed of the six possible hybrids (Burton, 1948). Alternatively, if two plants are identified that are self-sterile but cross fertile and produce superior $F_{1}$ hybrids, then the two plants can be vegetatively increased and transplanted into seed production fields. All the seed harvested from the field would be $F_{1}$ hybrid seed assuming that proper isolation requirements were maintained. These seed fields could be maintained for many

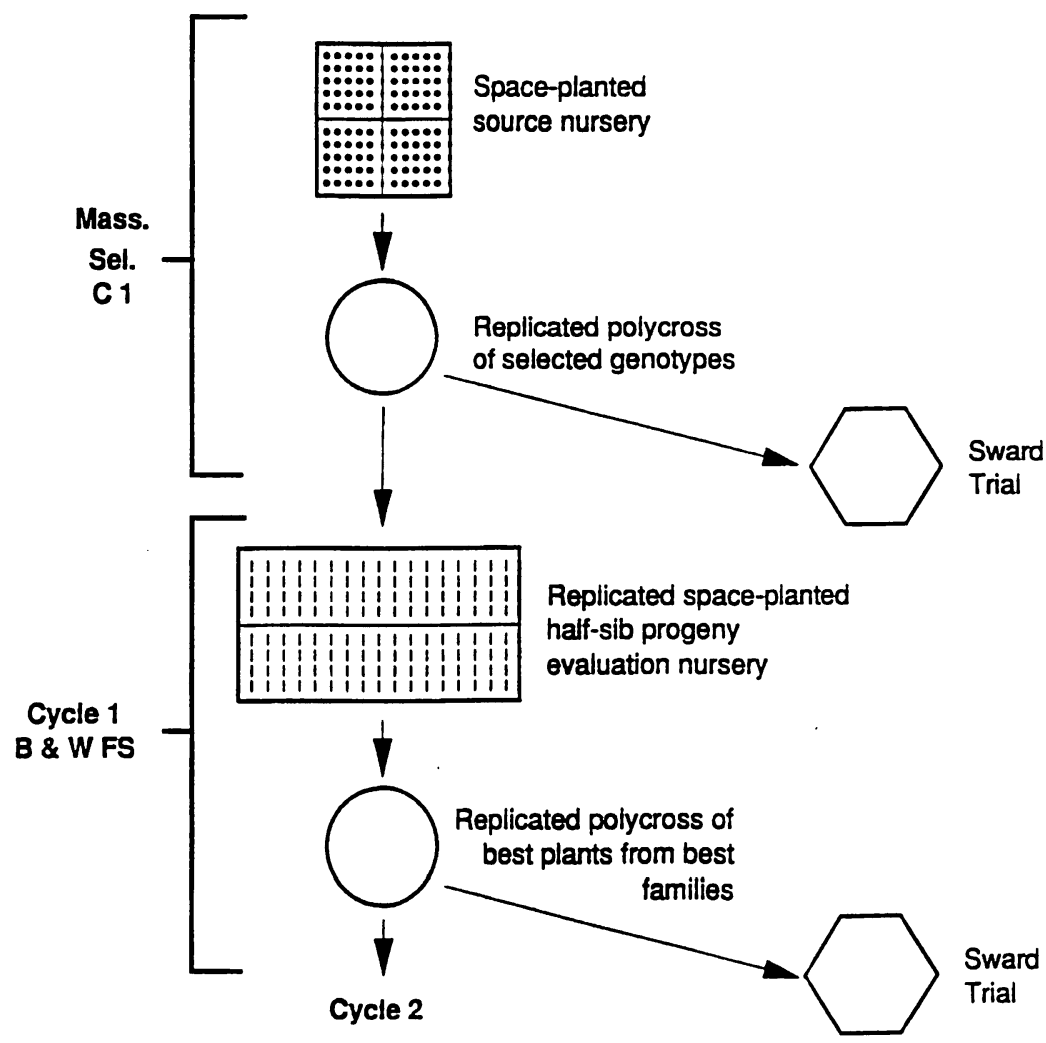

Fig. 6-4. Recurrent between and within half-sib family selection (B\&WFS). 


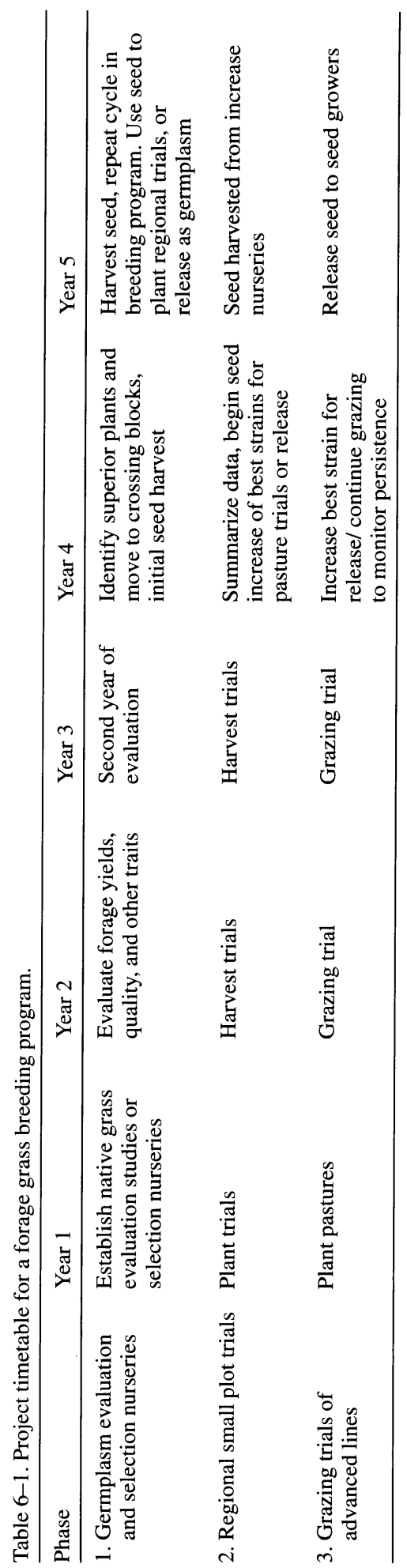


years. This method of producing hybrids is currently being evaluated at Lincoln, $\mathrm{NE}$. A method that has potential for producing hybrids is the use of male-gametocides in which a chemical is used to emasculate the female strain. Since many of these gametocides are proprietary compounds, the necessary research would have to be done in conjunction with firms that have ownership of the compounds.

Thus far, grass breeders have used conventional breeding techniques to develop new cultivars. New technologies are becoming available for breeders to greatly expand their capabilities to solve specific breeding problems. These technologies, which are referred to as cell culture and molecular genetics, must be used in conjunction with conventional breeding methods because their sole use would not result in the development and use of commercial cultivars. Techniques to culture individual plant cells and to regenerate plants from these cells have been developed for big bluestem, indiangrass, and switchgrass (Chen \& Boe, 1988; Denchev \& Conger, 1994). Tissue culture gives breeders the capability to rapidly and efficiently multiply individual plants that could make commercial self-incompatible hybrids feasible if somaclonal variation can be controlled. A new method for producing clonal propagules of switchgrass without somaclonal variation has recently been developed (Alexandrova et al., 1996).

Tissue culture also enables breeders to select and apply mutagenic treatments at the cellular level or to genetically alter plants via genetic transformation. A very effective transformation method involving particle bombardment is available for wheat (Weeks et al., 1993). Dr. Bob Conger has successfully transformed switchgrass using particle bombardment as indicated by marker genes (personal communication, 1997). The technology is available to develop effective transformation procedures for any monocot species if adequate financial, laboratory, and personnel resources are available. Molecular genetics techniques as applied to plant breeding will be used primarily to transfer traits to plants from very dissimilar organisms or to block expression of specific genes. Molecular genetics techniques permit the transfer of specific genes rather than whole blocks of genes. Traits that are being transferred into monocots include genes for insect, disease, and herbicide resistance and for unique proteins or other plant products. The main limitation for use of transformation procedures for grasses are the limited financial resources available for use on specific species and the high costs involved in getting transformed plants approved for use in production systems. Most forage programs simply do not have the resources to get transformed perennial grasses cleared for use in production agriculture. Because of the potential gene flow from cultivars to native populations of warm-season grasses, obtaining clearance to use transformed plants of native grasses in production agriculture may be more difficult than obtaining clearance for crops such as maize (Zea mays L.).

The objectives of most forage grass breeding programs are to improve one or more of the following traits: establishment capability, persistence, forage yield, forage quality, seed yield, and disease and insect resistance (Vogel et al., 1989).

\section{Improved Establishment}

Rapid and reliable establishment is critical for the conversion of cropland to grassland. Seedling establishment can be improved by either improving the estab- 
lishment capability of the plants by breeding or by modifying the environment with cultural practices. The primary causes of poor establishment are the related factors of moisture stress and weed competition. It is usually not feasible in the Great Plains to modify the environment by irrigating for grassland establishment.

Breeding for improved seedling vigor can result in seedlings that develop rapidly and that are effective competitors with weeds for available moisture and sunlight. Factors that affect seedling vigor are seed size, seed quality, germination rate, emergence rate, relative growth rates and other physiological processes (McKell, 1972). In virtually all the studies that have been done to date, seed size or weight has been an important component of seedling establishment capability (Asay \& Johnson, 1987; Voight et al.,1987, Kneebone, 1956). Breeding for improved seed size can result in strains with improved seedling growth and establishment (Trupp \& Carlson, 1971; Wright, 1977; Clements and Latter, 1973).

Seed size, however, is only one component of seedling growth. Whalley et al. (1966) subdivided seedling growth into a heterotrophic, transition, and autotrophic stages. The heterotrophic stage included all physiological activities prior to the initiation of photosynthesis, and the autotrophic stage occurs after all endosperm reserves have been depleted. The effect of seed size probably occurs in the heterotrophic and transitional stages and it may have a carryover effect in the autotrophic stage. Variation for seedling growth within a species therefore is due to variation for seed weight and seedling vigor. In sand bluestem, $50 \%$ of the genetic variability for seedling weight $8 \mathrm{wk}$ after establishment was due to seed size differences while the remainder was due to other factors (Glewen \& Vogel, 1984). Seedling vigor is difficult to measure in grasses because it can be affected by growing conditions in seed production fields, seed harvesting, handling, storage procedures, and by varying degrees of seed dormancy when seeds are planted in soils varying in temperature.

Two procedures recently have been used to successfully breed for improved seedling vigor in native, warm-season grass. I (Sebolai \& Vogel, 1989) used stratified mass selection to select for individual seedling weight of big bluestem, switchgrass, and indiangrass grass seedlings grown in individual micro-pots (cone-tainer cells). Seedlings were cut and weighed $6 \mathrm{wk}$ after planting, the heaviest seedlings were allowed to regrow, and then were transplanted into field polycross nurseries. Three cycles of selection have been competed in switchgrass, big bluestem, and indiangrass populations. Evaluation trials have indicated that significant improvements in seedling vigor have been made using this procedure (Sebolai Vogel, 1989). Boe and Johnson (1987) conducted mass selection for seed size in a switchgrass population by separating heavy seed from light seed with a seed blower and significantly improved seed size. Selection for seedling weight or seed size could be used in tandem with selection for other traits such as forage quality.

\section{Persistence}

Developing cultivars from germplasm indigenous to the region of use or from an area of the world with similar climate and soils is the primary procedure that is used to breed for persistence (Vogel et al., 1989; Hanson \& Carnahan, 1956). Persistence problems with native warm-season grasses can be solved by using culti- 
vars that originate from the same Plant Hardiness Zone in which they are used in production agriculture. Persistence problems develop when cultivars are moved too far north or south from their latitude of origin. Because germplasm resources for switchgrass, big bluestem, and indiangrass are available for most areas where they will be used, it usually is easier to use adapted material in breeding programs rather than attempting to change the adaptability of a strain by breeding.

Breeding work to improve disease and insect resistance can improve persistence; however, sometimes breeding for specific traits can affect persistence adversely. Recently completed research on a switchgrass population that has gone through three cycles of selection for high IVDMD has indicated that breeding work to increase IVDMD has produced a population with reduced ability to survive $\mathrm{Ne}$ braska winters (Vogel, 1991-1995, unpublished data). Some families in the population, however, have good winter survival indicating that it should be possible to continue to improve IVDMD but attention will have to be given to persistence. Bahiagrasses selected for high yield in a rapid generation RRPS program also showed reduced winter survival in Florida (Pedreira \& Brown, 1996). Although rapid generation turnover theoretically can maximize gain from selection, these results indicate that perennials expected to persist in production pastures for $10 \mathrm{yr}$ or longer may require longer evaluation periods in breeding nurseries.

\section{Seed Yields}

Initially, seed production was a problem with most perennial grasses adapted to the Great Plains. Empirical (Schumacher, 1962) and formal research (Cornelius, 1950; Kassel et al., 1985) has resulted in greatly increased seed production. By using improved seed production practices, experienced seed growers in Nebraska can produce from 250 to $>1000 \mathrm{~kg}$ of seed $\mathrm{ha}^{-1}$ (Nebraska Crop Improvement Association, 1990 , personal communications). Since only 6 to $14 \mathrm{~kg}$ of pure live seed ha${ }^{1}$ are needed for grassland plantings, one seed production hectare will plant 25 to 90 ha of grasslands, which is similar to that of most cultivated crops (Vogel et al., 1989). Breeding for seed yield for species where seed yields are adequate and the end product is biomass thus does not appear to be warranted.

The low seed yields that occur periodically in the region probably are due to insect predation. A big bluestem seed midge (Contarinia wattsi Gagné) can reduce yields of these grasses by $>50 \%$ (Carter et al., 1988). Limited information on the biology of the bluestem seed midge is available (Vogel \& Manglitz, 1989). Systemic insecticides may be effective but two that were evaluated, carbofuran and orthene, were not effective in reducing seed losses (Vogel \& Manglitz, 1990). Based on existing knowledge of the insect, it is likely that light applications of insecticides timed to match the emergence of the adult could be an effective control. Evaluating nonsystematic insecticides will require multiple isolated fields in which treatments can be applied. Boe et al. (1989) recently reported evidence that there may be genetic variation for infestation by the big bluestem seed midge. The genetic differences were small and a tremendous amount of long-term breeding work $(20+y r)$ would be required to produce strains that had economically improved tolerance or resistance. A limited amount of entomological work on finding a suitable insecticide 
would be a better use of research funds. Seed midges also have been reared from midge pupae found in indiangrass and little bluestem (Vogel \& Manglitz, 1989).

\section{Disease and Insect Resistance}

Grass breeders have made significant improvements in disease tolerance and resistance of forage grasses including native warm-season grasses. Virtually every improved cultivar on the market today is superior in disease resistance to common strains or native collections. Additional genetic gains in disease resistance can be made by continued selection for plants free from diseases in breeding programs. Genetic sources of resistance have been reported for almost every disease of economically important cool-season grasses (Braverman, 1986). A similar situation probably exists in warm-season grasses. A problem with breeding for disease resistance in warm-season grasses has been the lack of basic plant pathology work on disease characterization and identification. Research by Zeiders (1982, 1984) and Snetskaar and Tiffany (1990) on diseases affecting warm-season grasses has been very helpful.

\section{Forage Yield}

Improving forage yield always has been one of the principal objectives of grass breeders. The easiest way to breed for improved yield in native warm-season grasses is to move southern strains north. There is a problem associated with this approach since strains moved too far north will winter kill. For example, switchgrass strains from southern Oklahoma and Texas do not survive Nebraska winters. Recent reports document that forage yields can be improved significantly by breeding with substantial economic benefits (Vogel et al., 1989). Burton $(1982,1985)$ improved forage yield of bahiagrass (Paspalum notatum Fluegge) by direct selection for yield using RRPS. Nelson et al. (1985) improved forage yield of tall fescue (Festuca arundinaceae Schreber) by selection for leaf area expansion rate. These breeding efforts were successful because the breeders either selected directly for yield or for a trait that was correlated with yield, and they used recurrent selection methods that effectively exploited the additive genetic variability for the selected traits within the species. It should be possible to improve yield of most forage grasses by using well-designed recurrent selection methods. Breeding for yield remains a valid research objective.

\section{Forage Quality}

An extensive review of breeding for forage quality was completed recently by Vogel and Sleper (1994). Forage quality can be improved by breeding for enhanced positive quality factors such as digestibility or for reduced negative factors such as alkaloids (Burton, 1981; Marten, 1989). There are no reported problems in big bluestem with any anti-quality factors such as alkaloids or endophytes. Pouli et al. (1992) reported that a photo-sensitization factor is present in switchgrass that affects sheep. In the Central Great Plains and the Midwestern states, switchgrass 
is largely used by beef cattle so the reported photo-sensitization factor has not been a problem in these regions. Indiangrass contains dhurrin (a cyanogenic compound) that can cause prussic acid poisoning of livestock (Gorz et al., 1979). The hydrocyanic acid potential ( $\mathrm{HCN}-\mathrm{p}$ ) of indiangrass exceeds critical levels only in new growth of pure stands of indiangrass that is $<20 \mathrm{~cm}$ tall (Vogel et al., 1987). Indiangrass in mixed stands in seed pastures would be diluted by other grasses and forbs so the potential for hydrocyanic poisoning of livestock is reduced. No deaths of livestock due to grazing indiangrass have been reported.

Emphasis in breeding programs can be placed on improving positive quality factors because of the limited anti-quality problems of big bluestem, switchgrass, and indiangrass. Significant gains have been made in improving digestibility of switchgrass that has resulted in improved animal performance (Anderson et al., 1988; Vogel et al., 1993). Increased quality results in increased net return to a livestock producer and does not require any additional investment. Increased yield can increase net return, but the producer must buy or raise additional livestock to use the additional forage. Digestibility of forage is primarily determined by the plant cell walls that are composed of cellulose, hemicellulose, and lignin. Factors affecting cell wall digestion are complex and are related to lignin concentration and composition. Cell wall composition including lignin composition is under genetic control. Fortunately, the in vitro dry matter digestibility test measures the cumulative effects of the various factors and gives forage breeders a single value upon which to make selections. Genetic variation exists in switchgrass, indiangrass, and big and sand bluestem for forage digestibility (Godshalk et al., 1986; Riley, 1981; Ross et al., 1975, Vogel et al., 1981a,b) so genetic gains to improve IVDMD of these grasses can be achieved. The development of instruments, associated software, and procedures for such methodology as near infrared reflectance spectroscopy (NIRS), high performance liquid chromatography (HPLC), gas chromatography, and other procedures has greatly expanded the capability of grass breeders to select for specific plant composition and constituents.

Currently research is in progress to modify plant cell walls by using molecular genetics technology to block or alter specific steps in the lignin synthesis pathway using anti-sense technology. Transgenic tobacco with altered cell walls has been produced (Halpin et al., 1994). This technology can be transferred to monocots and will probably be applied to annual monocot crops such as maize grown for silage. Using this technology on perennial, polyploid grasses will be more difficult because the affect of specific pathways on the persistence of perennials is unknown. Even after transformed plants are developed, the expense of clearing transformed plants for use in production agriculture will exceed the capability of most forage breeding programs. Because significant levels of natural variation exist in most forage grasses for forage quality traits (Vogel \& Sleper, 1994), this source of genetic variation should be exploited before more expensive genetic transformation procedures are used.

\section{CULTIVARS}

Cultivars of big bluestem, switchgrass, and indiangrass have been developed and released by state experiment stations, by USDA-ARS breeding programs, and 
by the Plant Material Centers of USDA-NRCS. The principal cultivars that are available for use as forage grasses are summarized in Tables 6-2, 6-3, and 6-4 for switchgrass, big and sand bluestem, and indiangrass, respectively. The adaptation zone for cultivars can be based on the USDA Plant Hardiness Zone Map (Fig. 6-5) since

Table 6-2. Principal cultivars of switchgrass and their areas of adaptation. Origin is area where germplasm for cultivars was collected. Adaptation zones are indicated on USDA Plant Hardiness Zone Map (Fig.6-5).

\begin{tabular}{lllcl}
\hline Cultivar & Origin & Type & $\begin{array}{c}\text { Chromosome } \\
\text { number }(2 n)\end{array}$ & $\begin{array}{c}\text { Adaptation } \\
\text { zone }\end{array}$ \\
\hline Dacotah & North Dakota & upland & 36 & 2,3 , upper 4 \\
Forestburg & South Dakota & upland & 72 & 3,4 \\
Sunburst & South Dakota & upland & 72 & 3,4 \\
Nebraska 28 & Nebraska & upland & 72 & 3,4 \\
Summer & Nebraska & upland & 36 & $3,4,5$ \\
Pathfinder & Nebraska, Kansas & upland & 72 & 4,5 \\
Trailblazer & Nebraska, Kansas & upland & 72 & 4,5 \\
Blackwell & Oklahoma & upland & 72 & lower 5, 6, 7 \\
Cave-in-Rock & Southern Illinois & upland & 72 & $5,6,7$ \\
Shawnee & Southern Illinois & upland & 72 & 5,6 \\
Shelter & West Virginia & upland & 72 & 4,5 \\
Kanlow & Oklahoma & lowland & 36 & 6,7 \\
Alamo & Texas & lowland & 36 & $7,8,9$ \\
\hline
\end{tabular}

Table 6-3. Principal cultivars of big and sand bluestem and their areas of adaptation. Origin is area where germplasm for cultivars was collected. Adaptation zones are indicated on USDA Plant Hardiness Zone Map (Fig. 6-5).

\begin{tabular}{lllcl}
\hline Cultivar & Origin & Type & $\begin{array}{c}\text { Chromosome } \\
\text { number }(2 n)\end{array}$ & $\begin{array}{c}\text { Adaptation } \\
\text { zone }\end{array}$ \\
\hline Bison & North Dakota & big bluestem & 60 & 2,3 \\
Bonilla & South Dakota & big bluestem & 60 & 3, upper 4 \\
Niagara & New York & big bluestem & 60 & 3,4 , upper 5 \\
Champ & Nebr., Iowa & intermediate & 60 & 4 \\
Pawnee & Nebraska & big bluestem & 60 & lower 4, 5 \\
Rountree & Iowa & big bluestem & 60 & 4,5, upper 6 \\
Garden & Nebraska & sand bluestem & & 4,5 \\
Goldstrike & Nebraska & sand bluestem & 60 & 4,5 \\
Kaw & Kansas & big bluestem & 60 & lower 5, 6, 7 \\
Earl & Texas & big bluestem & 60 & 7,8 \\
\hline
\end{tabular}

Table 6-4. Principal cultivars of indiangrass and their areas of adaptation. Origin is area where germplasm for cultivars was collected. Adaptation zones are indicated on USDA Plant Hardiness Zone Map (Fig. 6-5).

\begin{tabular}{llcl}
\hline Cultivar & Origin & Chromosome number $(2 n)$ & Adaptation zone \\
\hline Tomahawk & North \& South Dakota & & 3 , upper 4 \\
Holt & Nebraska & 40 & 4 \\
Nebraska 54 & Nebraska & 40 & lower 4,5 \\
Oto & Nebraska, Kansas & 40 & 5 , upper 6 \\
Rumsey & Illinois & & 5,6 \\
Osage & Kansas, Oklahoma & 40 & 6,7 \\
Lometa & Texas & & lower 6, 7,8 \\
Llano & New Mexico & & 7,8 \\
\hline
\end{tabular}




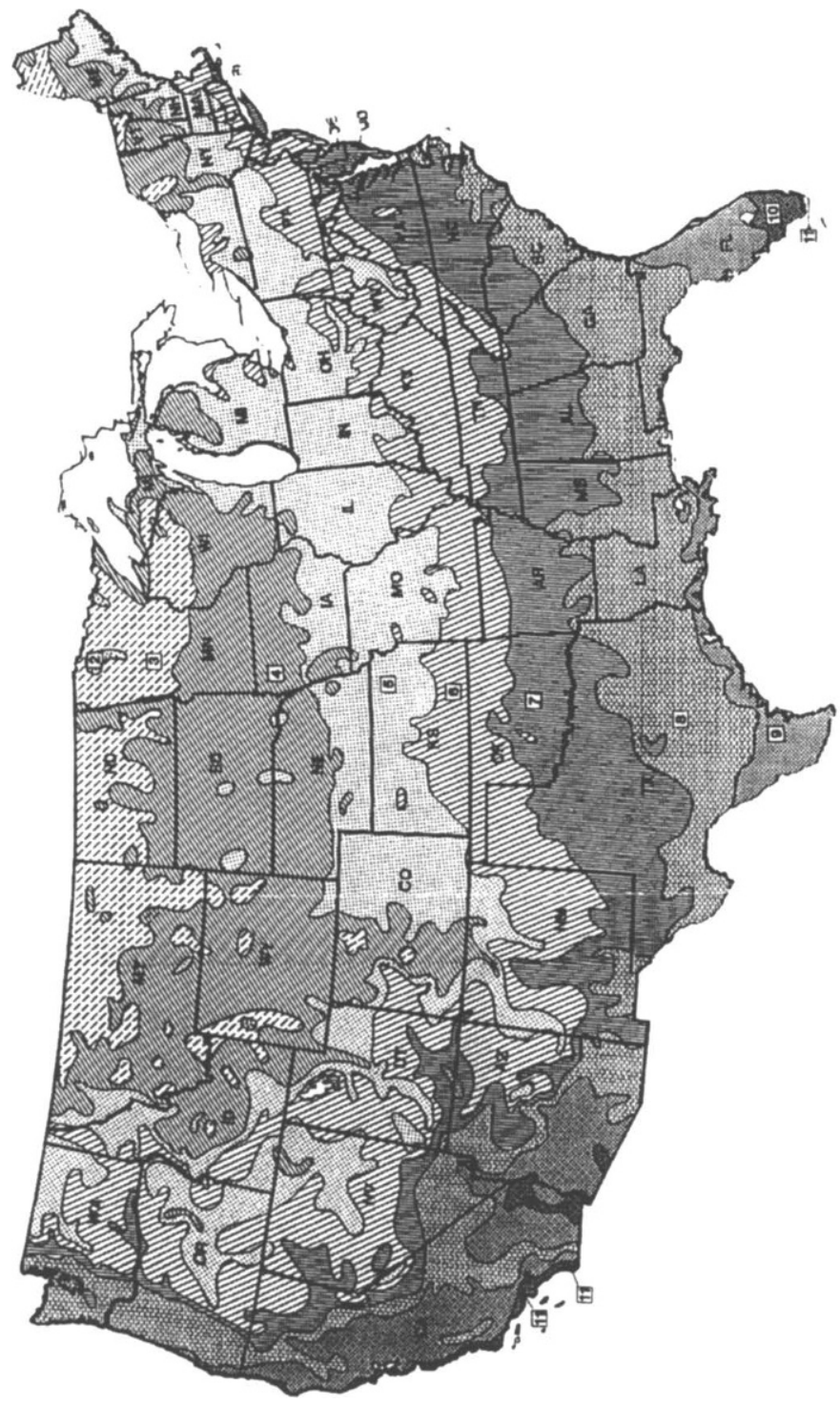

4
4
4
0
0
0 目圆同閣

는는ㄷㄴ는

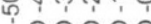

간아안아난

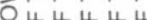

붕융ㅇํ융ㅇㅇ and $-N m \forall \ln \theta$

岁岂岂岂

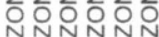

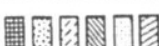


photoperiod response as determined by latitude of origin and length of the growing season are the primary factors affecting cultivar adaptation to specific regions. The released cultivars of these grasses are best adapted and are most productive in areas where annual precipitation exceeds $450 \mathrm{~mm}$.

\section{SUMMARY}

Substantial genetic variation exists among and within populations of switchgrass, big bluestem, and indiangrass. Cultivars have been developed for most geographic regions but in comparison to most cultivated species, the breeding work on these species has been limited and substantial genetic improvements are feasible. Improved breeding methods and equipment are available to develop improved cultivars of these species for use in grassland agriculture.

\section{REFERENCES}

Allard, R.W. 1964. Principles of plant breeding. John Wiley \& Sons, New York.

Anderson, Bruce, J.K. Ward, K.P. Vogel, M.G. Ward, H.J. Gorz, and F.A. Haskins. 1988. Forage quality and performance of yearlings grazing switchgrass strains selected for differing digestibility. J. Anim. Sci. 66:2239-2244.

Alexandrova, K.S., P.D. Denchev, and B.V. Conger. 1996. In vitro development of inflorescences from switchgrass nodal segments. Crop Sci. 36:175-178.

Alderson, J., and W.C. Sharp. 1994. Grass varieties in the United States. USDA-SCS Agric. Handb. 170. U.S. Gov. Print. Office, Washington, DC.

Asay, K.H., and D.A. Johnson. 1987. Breeding for improved seedling establishment in cool-season range grasses. p.173-176. In G.W. Frasier and R.A. Evans (ed.) Proc. of Symp. on Seed and Seedbed Ecology of Rangeland Plants, Tucson, AZ. 21-23 Apr. 1987. USDA-ARS Natl. Tech. Information Serv., Springfield, VA.

Asstveit, A.H., and K. Asstveit. 1990. Theory and application of open-pollination and polycross in forage breeding. Theor. Appl. Genet. 79:618-624.

Barnes, P.W. 1986. Variation in the big bluestem (Andropogon gerardii)-sand bluestem (Andropogon hallii) complex along a local dune/meadow gradient in the Nebraska Sandhills. Am. J. Bot. 73:172-184.

Barnett, F.L., and R.F. Carver. 1967. Meiosis and pollen stainability in switchgrass, Panicum virgatum L. Crop Sci. 7:301-304.

Barnett, F.L., Z.E. Rafil, and R.L. Vanderlip. 1971. Seed yield, seed quality, and total establishment capability of indiangrass. Crop Sci. 11:644-647.

Barnett, F.L., and R.L. Vanderlip. 1969. Criteria of field establishment capability in indiangrass, Sorghastrum nutans (L.) Nash. Crop Sci. 9:290-293.

Benedict, H.M. 1941. Effect of day length and temperature on the flowering and growth of four species of grasses. J. Agric. Res. 61:661-672.

Boe, A., and P.O. Johnson. 1987. Deriving a large-seeded switchgrass population using air-column separation of parent seed. Crop Sci. 27:147-148.

Boe, A., K. Robbins, and B. McDaniel. 1989. Spikelet characteristics and midge predation of hermaphroditic genotypes of big bluestem. Crop Sci. 29:1433-1435.

Boe, A.A., and J.G. Ross. 1983. Path coefficient analysis of seed yield in big bluestem. J. Range Manage. 36:652-653.

Boe, A.A., J.G. Ross, and R. Wynia. 1983. Pedicellata spikelet fertility in big bluestem from eastern South Dakota. J. Range Manage. 36:131-132.

Bragg, L.H. 1964. Chromosome counts and cytological observations of certain Texas Graimineae under transplanted conditions. Southwest Nat. 9:306-308.

Braverman, S.W. 1986. Disease resistance in cool-season forage and forage range and turf grass II. Bot. Rev. 52:1-112. 
Brown, R.R., J. Henry, and J. Crowder. 1983. Improved processing for high quality seedfor big bluestem (Andropogon gerardii) and yellow indiangrass (Sorghastrum nutans). p.272-274. In J.A. Smith and V.W. Hays (ed .) Proc. 14th Int. Grassl. Congr., Lexington, KY. 15-24 June 1981. Westview Press, Boulder, CO.

Brunken, J.N., and J.R. Estes. 1975. Cytological and morphological variation in Panicum virgatum L. Southwest Nat. 19:379-385.

Burton, G.W. 1948. The performance of various mixtures of hybrid and parent inbred millet. J. Am. Soc. Agron. 40:908-915.

Burton, G.W. 1974. Recurrent restricted phenotypic selection increases forage yields of Pensacola bahiagrass. Crop Sci. 14:831-835.

Burton, G.W. 1981. Nutrient composition of forage crops. Effects of genetic factors. USDA-ARS Agric. Rev. Manuals. ARM-S-21. USDA, Washington, DC.

Burton, G.W. 1982. Improved recurrent restricted phenotypic selection improves Bahia forage yields. Crop Sci. 22:1058-1061.

Burton, G.W. 1985. Spaced-plant-population-progress test. Crop Sci. 25:63-65.

Burton, G.W. 1986. Developing better forages for the south. J. Anim. Sci. 63:63-65.

Carter, M.R., G.R. Manglitz, M.D. Rethwisch, and K.P. Vogel. 1988. A seed midge pest of big bluestem. J. Range Manage. 41:253-254.

Chen, C.H., and A.A. Boe. 1988. Big bluestem (Andropogaon gerardii Vitman), little bluestem [Schizachyrium scoparius (Michx.) Nash], and indiangrass [Sorghastrum nutans (L.) Nash]. p. 444-457. In Y.P.S. Bajaj (ed.) Biotechnology in agriculture and forestry. Vol. 6. Crops II. Springer-Verlag, Berlin.

Church, G.L. 1929. Meiotic phenomena in certain Gramineae: II. Paniceae and Andropogoneae. Bot. Gaz. 88:63-64.

Clements, R.J., and B.D.H. Latter. 1973. Responses to selection for seed weight and seedling vigor in phalaris. Aust. J. Agric. Res. 25:33-34.

Cornelius, D.R. 1950. Seed production of native grasses. Ecol. Mono. 20:1-27.

Cornelius, D.R., and C.O. Johnston. 1941. Differences in plant type and reaction to rust among several collections of Panicum virgatum L. J. Am. Soc. Agron. 33:115-124.

Denchev, P.D., and B.V. Conger. 1994. Plant regeneration from callus culture of switchgrass. Crop Sci. 34:1623-1627.

Dewald, G.W., and S.M. Jahal. 1977. Meiotic behavior and fertility interrelationships in Andropogon scoparius and $A$. gerardii. Cytologia. 39:214-223.

Eberhardt, S.A., and L.C. Newell. 1959. Variation in domestic collections of switchgrass, Panicum virgatum L. Agron. J. 51:613-616.

Emal, J.G., and E.C. Conard. 1973. Seed dormancy and germination in indiangrass as affected by light, chilling, and certain chemical treatments. Agron. J. 81:47-52.

Falconer, D.S. 1981. Introduction to quantitative genetics 2nd ed. Longman, New York.

Gabrielsen, B.C., K.P. Vogel, B.E. Anderson, and J.K. Ward. 1990. Alkali-labile lignin phenolics and forage quality in three switchgrass strains selected for differing digestibility. Crop Sci. 30:1313-1320.

Glewen, K.L., and K.P. Vogel. 1984. Partitioning the genetic variability for seedling growth in sand bluestem into its seed size and seedling vigor components. Crop Sci. 24:137-141.

Godshalk, E.B., J.C. Burns, and D.H. Timothy. 1986. Selection for in vitro dry matter digestibility disappearance in switchgrass regrowth. Crop Sci. 26:943-947.

Godshalk, E.B., and D.H. Timothy. 1988a. Factor and principal component analyses as alternatives to index selection. Theor. Appl. Genet. 76:352-360.

Godshalk, E.B., and D.H. Timothy. 1988b. Effectiveness of index selection for switchgrass forage yield and quality. Crop Sci. 28:825-830.

Godshalk, E.B., W.F. McClure, J.C. Burns, D.H. Timothy, and D.S. Fisher. 1988a. Heritability of cell wall carbohydrates in switchgrass. Crop Sci. 28:736-742.

Godshalk, E.B., D.H. Timothy, and J.C. Burns. 1988b. Application of multistage selection indices to crop improvement. Crop Sci. 28: 23-26.

Gorz, H.J., F.A. Haskins, R. Dam, and K.P. Vogel. 1979. Dhurrin in Sorghastrum nutans. Phytochemistry 18:20-24.

Gould, F.W. 1968. Grass systematics. McGraw-Hill Book Co., New York.

Gould, F.W. 1975. The grasses of Texas. Texas A\&M Univ. Press, College Station.

Gunter, L.E., G.A. Tuskan, and S.D. Wullschleger. 1996. Diversity among populations of switchgrass based on RAPD markers. Crop Sci. 36:1017-1022. 
Halpin, C., M.E. Knight, B.A. Foxon, M.M. Campbell, A.M. Boudet, J.J. Boon, B. Chabbert, M-T. Tollier, and W. Schuch. 1994. Manipulation of lignin quality by down regulation of cinnamyl alcohol dehydrogenase. Plant J. 6:339-350.

Hallauer, A.R., and J.B. Miranda, OF. 1981. Quantitative genetics in maize breeding. Iowa State Univ. Press, Ames.

Hanson, A.A., and H.L. Carnahan. 1956. Breeding perennial forage grasses. USDA-ARS Agric. Tech. Bul. 1145. USDA, Washington, DC.

Hitchcock, A.S. 1971. Manual of grasses of the United States. 2nd ed. Dover Publ., New York.

Hopkins, A.A., K.P. Vogel, and K.J. Moore. 1993. Predicted and realized gains from selection for in vitro dry matter digestibility and forage yield in switchgrass. Crop Sci. 32:253-258.

Hopkins, A.A., K.P. Vogel, K.J. Moore, K.D. Johnson, and I.T. Carlson. 1995a. Genetic effects and genotype by environment interactions for traits of elite switchgrass populations. Crop Sci. 35:125-132.

Hopkins, A.A., K.P. Vogel, K.J. Moore, K.D. Johnson, and I.T. Carlson. 1995b. Genetic variability and genotype $x$ environment interactions among switchgrass accessions from the Midwestern USA. Crop Sci. 35:565-571.

Hopkins, A.A., C.M. Taliaferro, C.D. Murphy, and D. Christian. 1996. Chromosome number and nuclear DNA content of several switchgrass populations. Crop Sci. 36:1192-1195.

Hultquist, S.J., K.P. Vogel, D.J. Lee, K. Arumuganathan, and S. Kaeppler. 1996. Chloroplast DNA and nuclear DNA content variations among cultivars of switchgrass, Panicum virgatum L. Crop Sci. 36:1049-1052.

Hultquist, S.J., K.P. Vogel, D.E. Lee, K. Arumuganathan, and S. Kaeppler. 1997. Nuclear DNA content and chloroplast DNA polymorphisms among accessions of Panicum virgatum L. from remnant Midwestern prairies. Crop Sci. 37:595-598.

Johnson, P., and A.A. Boe. 1982. Seed size variation in three switchgrass (Panicum virgatum L.) varieties. Proc. S. Dak. Acad. Sci. 61:159.

Jones, M.D., and L.C. Newell. 1946. Pollination cycles and pollen dispersal in relation to grass improvement. Nebraska Agric. Exp. Stn. Res. Bull. 148. Nebraska Agric. Exp. Stn., Lincoln.

Jones, M.D., and L.C. Newell. 1948. Size, variability, and identification of grass pollen. J. Am. Soc. Agron. 40:136-143.

Kassel, P.C., R.E. Mullen, and T.B. Bailey. 1985. Seed yield response of three switchgrass cultivars for different management practices. Agron. J. 77:214-218.

Keeler, K.H. 1990. Distribution of polyploid variation in big bluestem (Andropogon gerardii) across the tallgrass prairie region. Genome 33:95-100.

Keeler, K.H. 1992. Local polyploid variation in the native prairie grass Andropogon gerardi. Am. J. Bot. 79:1229-1232.

Kneebone, W.R. 1956. Breeding for seedling vigor in sand bluestem (Andropogon hallii Hack.) as estimated from parental clones and their open-pollinated progenies. Agron. J. 50:459-461.

Kube, J.G., K.P. Vogel, and L.E. Moser. 1989. Genetic variability for seedling atrazine tolerance in indiangrass (Sorghastrum nutan). Crop Sci. 29:18-23.

Law, A.G., and K.L. Anderson. 1940. The effect of selection and inbreeding on the growth of big bluestem (Andropogon furcatus Muhl.). J. Am. Soc. Agron. 32:931-943.

Lu, Ku, S.M. Kaeppler, K.P. Vogel, and K. Arumuganathan. 1998. Nuclear DNA content and chromosome numbers on switchgrass. Great Plains Res. 8:269-280.

Marten, G.C. 1989. Breeding forage grasses to maximize animal performance. p. 71-104. In D.A. Sleper et al. (ed.) Contributions from breeding forage and turf grasses. CSSA Spec. Publ. 15. CSSA, Madison, WI.

McKell, C.M. 1972. Seedling vigor and seedling establishment. p. 76-89. In V.B. Younger and C.M. McKell (ed.). The biology and utilization of grasses. Academic Press, New York.

McKendrick, J.D., C.E. Owensby, and R.M. Hyde. 1975. Big bluestem and indiangrass vegetative reproduction and annual reserve carbohydrate and nitrogen cycles. Agric. Ecosyst. 2:75-93.

McMillian, C. 1959. The role of ecotypic variation in the distribution of the central grassland of North Am. Ecol. Mono. 29:285-308.

McMillan, C. 1965. Ecotypic differences within four North American prairie grasses: II. Behavioral variation within transplanted community fractions. Am. J. Bot. 52:55-65.

Moser, L.E., and K.P. Vogel. 1995. Switchgrass, big bluestem, and indiangrass. p. 409-420. In R.F Barnes et al. (ed.). Forages. 5th ed. Vol. I. An introduction to grassland agriculture. Iowa State Univ. Press, Ames.

Nelson, C.J., D.A. Sleper, and J.H. Coutts. 1985. Field performance of tall fescue selected for leaf-area expansion. p. 320-322. In Proc. of the XV Int. Grassland Congr., Kyoto, Japan. 24-31 Aug. 1985. Japanese Soc. of Grassland Sci. and the Science Council of Japan, Tishi-nasuno, Tachigi-ken, Japan. 
Newell, L.C. 1968. Effects of strain source and management practice on forage yields of two warmseason prairie grasses. Crop Sci. 8:205-210.

Newell, L.C., and S.A. Eberhardt. 1961. Clone and progeny evaluation in the improvement of switchgrass. Crop Sci. 1:370-373.

Newell, L.C., and L.V. Peters. 1961. Performance of hybrids between divergent types of big bluestem and sand bluestem in relation to improvement. Crop Sci. 1:370-373.

Nielsen, E.L. 1944. Analysis of variation in Panicum virgatum. J. Agric. Res. 69:327-358.

Norrmann, G.L., C.L. Quarin, and K.H. Keeler. 1997. Evolutionary implications of meiotic chromosome behavior, reproductive biology, and hybridization in 6x and 9x cytotypes of Andropogon gerardii (Poaceae). Am. J. Bot. 84:201-207.

Pedersen, J.F., R.D. Lee, D.J. Lee, and K.P. Vogel. 1993. Comparison of sorghum and indiangrass chloroplast genomes using RFLPs. p. 196-2000. In Proc. American Forage and Grassland Council, Des Moines, IA. 29-31 Mar. 1993. Am. Forage and Grassland Council, Georgetown, TX.

Pedreira, C.G.S., and R.H. Brown 1996. Physiology, morphology, and growth of individual plants of selected and unselected bahiagrass populations. Crop Sci. 36(1):138-142.

Peters, L.V., and L.C. Newell. 1961. Hybridization between divergent types of big bluestem, Andropogon gerardii Vitman, and sand bluestem, Andropogon hallii Hack. Crop Sci. 1:359-363.

Porter, C.L. 1966. An analysis of variation between upland and lowland switchgrasses, P. virgatum, in central Oklahoma. Ecology 47:980-992.

Pouli, J.R., R.L. Reid, and D.P. Belesky. 1992. Photosensitization in lambs grazing switchgrass. Agron. J. 84:1077-1080.

Riley, R.D. 1981. Heritability of mature plant traits in sand bluestem. Ph.D. diss. Univ. of Nebraska, Lincoln.

Riley, R.D., and K.P. Vogel. 1982. Chromosome numbers of released cultivars of switchgrass, indiangrass, big bluestem, and sand bluestem. Crop Sci. 22:1081-1083.

Ross, J.G., R.T. Thaden, and W.L. Tucker. 1975. Selection criteria for yield and quality in big bluestem (Andropogon gerardi Vitman). Crop Sci. 15:303-306.

Schumacher, C.M. 1962. Grass production in Nebraska and South Dakota. USDA-SCS Technical Guide-Section IV-G. USDA, Washington, DC.

Sebolai, B., and K.P. Vogel. 1989. Evaluation of three cycles of mass selection for seedling weight in switchgrass, indiangrass, and big bluestem. p. 99. In Agronomy abstracts. ASA, Madison, WI.

Snetselaar, K.M., and L.H. Tiffany. 1990. Light and electron microscopy of sorus development in Sorosporium provinciale, a smut of big bluestem. Mycologia 82:480-492.

Stubbendieck, J., S.L. Hatch, and C.H. Butterfield. 1991. North American range plants. Univ. of Nebraska Press, Lincoln.

Talbert, L.E., D.H. Timothy, J.C. Burns, J.O. Rawlings, and R.H. Moll. 1983. Estimates of genetic parameters in switchgrass. Crop Sci. 23:725-728.

Trupp, C.R. and I.T. Carlson. 1971. Improvement of seedling vigor of smooth bromegrass (Bromus inermis Leyss.) by recurrent selection for high seed weight. Crop Sci. 11:225-228.

Vogel, K.P. 1996. Energy production from forage or American agriculture: Back to the future. J. Soil Water Conserv. 51:137-139.

Vogel, K.P., and B.C. Gabrielsen. 1986. Breeding to improve native warm-season grasses. p. 27-34. In Warm-season grasses. Balancing forage programs in the northeast and southern Corn Belt. Soil Conserv. Soc. of Am., Ankeny, IA.

Vogel, K.P., R. Britton, H.J. Gorz, and F.A. Haskins. 1984. In vitro and in vivo analyses of hays of switchgrass strains selected for high and low IVDMD. Crop Sci. 24:977-980.

Vogel, K.P., H.J. Gorz, and F.A. Haskins. 1981a. Heritability estimates of forage yield, in vitro dry matter digestibility, crude protein, and heading date in indiangrass. Crop Sci. 21:35-38.

Vogel, K.P., H.J. Gorz, and F.A. Haskins. 1981b. Divergent selection for in vitro dry matter digestibility in switchgrass. Crop Sci. 21:39-41.

Vogel, K.P., H.J. Gorz, and F.A. Haskins. 1981c. Heritability estimates for height, color, erectness, leafiness, and vigor in indiangrass. Crop Sci. 21:734-736.

Vogel, K.P., H.J. Gorz, and F.A. Haskins. 1989. Breeding grasses for the future. p. 105-122. In D.A. Sleper et al. (ed.) Contributions from breeding forage and turf grasses. CSSA Spec. Publ. 15. CSSA. Madison, WI.

Vogel, K.P., F.A. Haskins, and H.J. Gorz. 1980. Parent-progeny regression in indiangrass: Inflation of heritability estimates by environmental covariances. Crop Sci. 20:580-582.

Vogel, K.P., F.A. Haskins, and H.J. Gorz. 1987. Potential for hydrocyanic acid poisoning of livestock by indiangrass (Sorghastrum nutans). J. Range Manage. 40:506-509. 
Vogel, K.P., A.A. Hopkins, K.J. Moore, K.D. Johnson, and I.T. Carlson. 1996. Registration of 'Shawnee' switchgrass. Crop Sci. 36:1713.

Vogel, K.P. and G.R. Manglitz. 1989. Effect of the big bluestem seed midge on the sexual reproduction of big bluestem: a review. p. 267-291. In T.B. Bragg and J. Stubbendieck (ed.) Proc. of the 11th North American Prairie Conf., Prairie Pioneers, Ecology, History, and Culture. Lincoln, NE. 7-11 Aug. 1988. Univ. of Nebraska, Lincoln.

Vogel, K.P., and G.R. Manglitz. 1990. Evaluation of Furadan and orthene against a bluestem seed midge, 1986 and 1987. Insect. Acaracide Tests 15:175-176.

Vogel, K.P., K.J. Moore, and A.A. Hopkins. 1993. Breeding switchgrass for improved animal performance. p. 1734-1735. In Proc. XVII Int. Grassland Congr., Palmerston North, Hamilton, Lincoln and Rockhampton, Australia, 8-21 Feb. 1993. New Zealand Grassland Society, Tropical Grasslands Soc. of Australia, New Zealand Soc. of Animal Production, Australian Soc. of Animal Production, and New Zealand Inst. of Agric. Sci.

Vogel, K.P., K.J. Moore, K.D. Johnson, and I.T. Carlson. 1994. Variation among indiangrass from Midwestern remnant prairies for agronomic traits. p. 220. In Agronomy abstracts. ASA, Madison, WI.

Vogel, K.P., and J.F. Pedersen. 1993. Breeding systems for cross-pollinated perennial grasses. Plant Breed. Rev. 11:251-274.

Vogel, K.P. and D.A. Sleper. 1994. Alteration of plants via genetics and plant breeding. p. 891-921. In G.C. Fahey, Jr. (ed.). Forage quality, evaluation, and utilization. ASA, CSSA, SSSA, Madison, WI.

Voight, P.W., C.R. Tischler, and B.A. Young. 1987. Selection for improved establishment in warm-season grasses. p. 177-187. In G.W. Frasier and R.A. Evans (ed.) Proc. Symp., Seed and Seedbed Ecology of Rangeland Plants, Tucson, AZ. 21-23 Apr. USDA-ARS, Washington, DC.

Vybiral, A.J., K.P. Vogel, K.J. Moore, K.D. Johnson, and I.T. Carlson. 1993. Variation among big bluestem from Midwestern remnant prairies for agronomic traits. p. 196. In Agronomy abstracts. ASA, Madison, WI.

Weaver, J.E. 1968. Prairie plants and their environment. Univ. of Nebraska Press, Lincoln.

Weeks, J.T., O.D. Anderson, and A.E. Blechl. 1993. Rapid production of multiple independent lines of fertile transgenic wheat (Triticum aestivum). Plant Physiol. 102:1077-1084.

Weimer, M.R., B.A. Swisher, and K.P. Vogel. 1988. Metabolism as a basis for inter- and intra-specific atrazine tolerance in warm-season grasses. Weed Sci. 36:436-440.

Whalley, R.D.B., C.M. McKell, and L.R. Green. 1966. Seedling vigor and the non-photosynthetic stage of seedling growth in grasses. Crop Sci. 6:147-150.

Wheeler, W.A., and D.D. Hill. 1957. Grassland seeds. D. Van Norstrand Co., Princeton, NJ.

Wright, L.N. 1977. Recurrent selection for shifting gene frequency of seed weight in Panicum antidotale Retz. Crop Sci. 17:176-178.

Zeiders, K.E. 1982. Leaf spots of big bluestem, little bluestem, and indiangrass caused by Ascochyta brachypodii. Plant Dis. 66:502-505.

Zeiders, K.E. 1984. Helminthosporium spot blotch of switchgrass (Panicum virgatum) in Pennsylvania. Plant Dis. 68:120-122. 